\title{
Features of the connective tissue metabolism, the content of adipokines and cytokeratin-18 in patients with non-alcoholic steatohepatitis combined with osteoarthritis and obesity
}

\author{
O. S. Khukhlina*E,F, O. D. Liakhovych ${ }^{\mathrm{A}, \mathrm{B}, \mathrm{C}}$, L. V. Kaniovska ${ }^{\mathrm{E}, \mathrm{B}}$, O. V. Kaushanska ${ }^{\mathrm{E}, \mathrm{B}}$, \\ V. O. Shuper ${ }^{\mathrm{E}, \mathrm{C}}$
}

Higher State Educational Establishment “Bukovinian State Medical University”, Chernivtsi, Ukraine

A - research concept and design; B - collection and/or assembly of data; C - data analysis and interpretation; D - writing the article; $\mathrm{E}$ - critical revision of the article; $\mathrm{F}$ - final approval of the article

Key words: nonalcoholic steatohepatitis, connective tissue, adipokines,

\section{Zaporozhye} medical journal 2019; 21 (4), 444-448

DOI:

10.14739/2310-1210

2019.4.173182

*E-mail:

oksanakhukhlina@

gmail.com cytokeratin-18.

Aim. To determine the indices of connective tissue metabolism, adipokines and cytokeratin-18 in non-alcoholic steatohepatitis patients with osteoarthritis and obesity comorbidities.

Materials and methods. 90 patients were examined and divided into three groups: group $1(n=30)$ included patients suffering from $O A$ grade II-III according to Kellgren and Lawrence classification with normal body mass $\left(B M I=21-25 \mathrm{~kg} / \mathrm{m}^{2}\right)$, group $2(n=30)$ - patients with $\mathrm{NASH}$ and $\mathrm{OB}$ without $\mathrm{OA}\left(\mathrm{BMl}>30 \mathrm{~kg} / \mathrm{m}^{2}\right)$, group $3(\mathrm{n}=30)$ - patients with $\mathrm{OA}$ with $\mathrm{NASH}$ and $\mathrm{OB}\left(\mathrm{BMl}\right.$ more than $\left.30 \mathrm{~kg} / \mathrm{m}^{2}\right)$. The control group consisted of 30 age-matched practically healthy persons (PHP). The average age of patients was $(62.3 \pm 5.7)$ years.

Results. In NASH patients with $\mathrm{OB}$ and $\mathrm{OA}$, there is a significant increase in the synthesis of collagen and glycosaminoglycans which is accompanied by ineffective resorption of newly formed collagen due to inhibition of the collagenolytic activity of blood plasma in NASH arising from activation of proteinase inhibitors ( $\alpha 2-\mathrm{MG}$ ), a significant imbalance in the metabolic system of connective tissue, which, particularly in $\mathrm{OA}$ and $\mathrm{OB}$ comorbidities, leads to progressive fibrosis of the liver and its functions impairment. It has been established that blood adipokines level not only depends on body weight, but also reflects the risk for occurrence of nosologies associated with OB.

Conclusions. In patients with NASH and morbid OB, a significant increase in collagen and glycosaminoglycans synthesis was observed. Adipokine deficiency, found in the work, can play a significant pathogenetic role in the development and progression of NASH as well as OB and OA. Adipokines leptin and adiponectin and also cytokeratin-18 may serve as sensitive risk markers for comorbid diseases development and could be candidates for their measurements inclusion in the diagnostic algorithm for $\mathrm{NASH}, \mathrm{OA}, \mathrm{OB}$ and their combination.

Киючові слова: неалкогольний стеатогепатит, сполучна тканина, аАипокіни, цитокератин-18.

Запорізький медичний журнал. - 2019. T. 21, № 4(115). C. 444-448
Особливості метаболізму сполучної тканини, вміст адипокінів і цитокератину-18 у хворих на неалкогольний стеатогепатит, що поєднаний з остеоартрозом та ожирінням

О. С. Хухліна, О. А. Аяхович, А. В. Каньовська, О. В. Каушанська, В. О. Шупер

Мета роботи - визначити показники обміну сполучної тканини, адипокінів і цитокератину-18 у хворих на неалкогольний стеатогепатит (НАСГ) за коморбідності з остеоартрозом (ОА) та ожирінням (ОЖ).

Матеріали та методи. Обстежили 90 пацієнтів, яких поділили на 3 групи: 1 група ( $n=30)$ - хворі, які страждають на ОА колін-

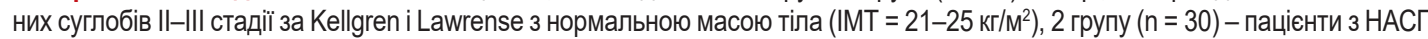
та ожирінням без ОА (IMT >30 кг/M²), 3 групу $(\mathrm{n}=30)$ - пацієнти з ОА, НАСГ та ожирінням (IMT понад $\left.30 \mathrm{kr} / \mathrm{M}^{2}\right)$. Контрольна група - 30 практично здорових осіб відповідного віку. Середній вік хворих становив 62,3 $\pm 5,7$ року.

Результати. У хворих на НАСГ, що поєднаний з ожирінням та остеоартрозом, встановили істотне підвищення синтезу колагену та глікозаміногліканів, котре супроводжується неефективною резорбцією новоутвореного колагену внаслідок гальмування колагенолітичної активності плазми крові при НАСГ, що виник унаслідок активації інгібіторів протеїназ (а2-МГ), дисбалансу в системі метаболізму сполучної тканини. Це, особливо за умов супутніх ОА та ОЖ, призводить до фіброзування печінки, що прогресує, та порушення її функцій. Встановлено, що рівень адипокінів у крові залежить не тільки від маси тіла, але й показує ризик виникнення нозологій, асоційованих із гладкістю.

Висновки. У хворих на неалкогольний стеатогепатит, що виник на тлі ожиріння, встановлено істотне підвищення синтезу колагену та глікозаміногліканів. Дефріцит адипонектину може відігравати важливу патогенетичну роль у розвитку та прогресуванні як НАСГ, так і ожиріння та остеоартрозу. Адипокіни лептин та адипонектин і цитокератин-18 можуть бути чутливими маркерами ризику розвитку коморбідних захворювань, а отже можуть стати кандидатами на включення їх визначення в діагностичний алгоритм при НАСГ, ОА і ОЖ та їх поєднанні.

\section{Особенности метаболизма соединительной ткани, содержание адипокинов и цитокератина-18 у больных с неалкогольным стеатогепатитом, совмещенным с остеоартрозом и ожирением}

\section{О. С. Хухиина, О. А. Аяховыч, А. В. Канёвская, Е. В. Каушанская, В. А. Шупер}

Цель работы - определить показатели обмена соединительной ткани, адипокинов и цитокератина-18 у больных с неалкогольным стеатогепатитом (НАСГ) при коморбидности с остеоартрозом (ОА) и ожирением (ОЖ). 
Материалы и методы. Обследовали 90 пациентов, которые разделены на 3 группы: 1 группу ( $n=30)$ составили больные,

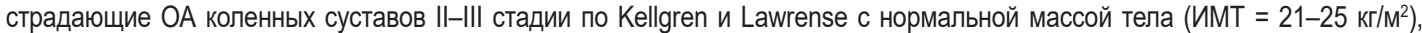

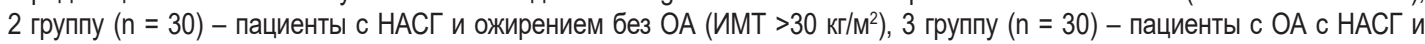
ожирением (ИМТ более 30 кг/М²). Контрольную группу составили 30 здоровых лиц соответствующего возраста. Средний возраст больных - 62,3 $\pm 5,7$ года.

Результаты. У больных НАСГ на фоне ожирения и остеоартроза установлено существенное повышение синтеза коллагена и гликозаминогликанов, которое сопровождается неэффективной резорбцией новосинтезированного коллагена вследствие торможения коллагенолитической активности плазмы крови при НАСГ, возникшем вследствие активации ингибиторов протеиназ (а2-МГ), дисбаланса в системе метаболизма соединительной ткани. Это, особенно в условиях сопутствующих ОА и ОЖ, приводит кпрогрессирующему фиброзированию печени и нарушению ее функций. Установлено, что уровень адипокинов в крови зависит не только от массы тела, но и отражает риск возникновения нозологий, ассоциированных с тучностью.

Выводы. У больных неалкогольным стеатогепатитом, который возник на фоне ожирения, установлено существенное повышение синтеза коллагена и гликозаминогликанов. Дефицит адипонектина может играть важную патогенетическую роль в развитии и прогрессировании как НАСГ, так и ожирения и остеоартроза. Адипокины лептин и адипонектин, а также цитокератин-18 могут быть чувствительными маркерами риска развития коморбидных заболеваний, а значит могут стать кандидатами на включение их определения в диагностический алгоритм при НАСГ, ОА и ОЖ и их сочетании.

\section{Relevance}

Modern achievements in hepatology have contributed to the recognition of the leading role of the connective tissue (CT) system in the pathogenesis of liver disease progression [7]. Liver fibrosis is a progressive pathological process that persists on the background of inflammation and leads to excessive matrix components accumulation in the extracellular space. If this process is accompanied by an ineffective resorption of the $\mathrm{CT}$, as well as an excessive regeneration, it leads to distortion of the normal liver architectonics, and as a consequence, to liver cirrhosis [5]. Scientists are currently attempting to find possible biochemical markers of liver fibrosis degree [11].

Osteoarthritis $(\mathrm{OA})$ is one of the most common diseases of joints, which is accompanied by a decrease in the quality of life and disability. Recently, the data on certain OA-related phenotypes were obtained. The age-associated, estrogen-dependent, genetically determined, pain, post-traumatic, crystalline-induced and metabolic ones are the most common OA phenotypes, which differ in pathogenetic processes and clinical manifestations $[3,10]$. Metabolic variant of OA phenotype is one of the most frequent and associated with metabolic syndrome and low-grade inflammation. It has become an interest of scientists to find the relationship between the components of metabolic syndrome, proinflammatory cytokines activity and the metabolic state of CT components in patients with OA.

Non-alcoholic fatty liver disease (NAFLD) is a potential component of the metabolic syndrome including a range of clinical and morphological concepts: liver steatosis, nonalcoholic steatohepatitis (NASH) and may be complicated by liver fibrosis and cirrhosis development. The pathogenetic causes of NAFLD are mostly insulin resistance (IR) and an imbalance in adipocytokines and hormone-like substances regulating fat metabolism. Adiponectin and leptin are biologically active compounds produced by adipose tissue, which are not only essential for lipids and carbohydrates metabolism regulation, but also affect the vascular wall state, inflammatory processes and thrombus formation. The literature data provide evidence that low levels of adiponectin are associated with the development of OB and IR. Other authors also point to the key role of leptin in the regulation of fat and carbohydrate metabolism as a link to atherosclerosis and NAFLD [1]. On the other hand, adipokines can play a certain role in the development of arthritis and osteoarthritis [2].

\section{Aim}

To determine the indices of connective tissue metabolism, adipokines and cytokeratin-18 in non-alcoholic steatohepatitis patients with osteoarthritis and obesity comorbidities.

\section{Materials and methods}

A total of 90 patients were examined and divided into three groups: group $1(n=30)$ included patients suffering from OA grade II-III according to Kellgren and Lawrence classification with normal body mass $\left(B M l=21-25 \mathrm{~kg} / \mathrm{m}^{2}\right)$, group $2(\mathrm{n}=30)$ - patients with NASH and OB without OA (BMI $\left.>30 \mathrm{~kg} / \mathrm{m}^{2}\right)$, group $3(n=30)$ - patients with OA with NASH and $\mathrm{OB}$ (BMI more than $30 \mathrm{~kg} / \mathrm{m}^{2}$ ). The control group consisted of 30 healthy age-matched individuals. The average age of patients was $62.3 \pm 5.7$ years.

NASH was diagnosed based on anamnestic, clinical, laboratory data, detection of the serum hepatitis $B$ and $C$ viruses markers, the results of USG according to the unified clinical protocol, approved by the Order of the Ministry of Health of Ukraine of 06.11.2014 No 826, in the presence of the criteria for exclusion of chronic diffuse liver disease of viral, hereditary, autoimmune or drug-induced genesis as causes of cholestatic or cytolytic syndromes, taking into account the 10th revision of ICE. OA was diagnosed based on the EULAR recommendations (2010) and the Order of the Ministry of Health of Ukraine of October 12, 2006, No 676 "Clinical Protocol for the Provision of Medical Aid to Patients with Osteoarthritis" under section 13 "Rheumatology" and the Protocol of the Ministry of Health of Ukraine of April 11, 2014, No 263 under section "Rheumatology". The presence of abdominal OB in patients was assessed based on the Order of the Ministry of Health of Ukraine of January 14, 2013 No 16 "Methodical Recommendations for General Practitioners of Family Medicine on Counseling Patients regarding the Basic Principles of Healthy Eating".

Changes in the metabolism of the extracellular matrix components were determined by free oxyproline (FOP) content in the blood according to S. S. Tetianets method (1985), protein-bound blood oxyproline (PBOP) by M. S. Osadchuk method (1979), hexosamines (HA) by O. G. Arhipova method (1988), sialic acids (SA), non-protein-bound fucose by "Danush Ltd" company sets (Lviv), ceruloplasmin (CP) with sets by Revin method (1976).
Ключевые слова: неалкогольный стеатогепатит, соединительная ткань, адипокины, цитокератин-18.

Запорожский медицинский журнал. - 2019. T. 21, № 4(115). C. $444-448$ 
Using ELISA kits, the serum levels of leptin (Diagnostics Biochem Canada Inc, Canada), adiponectin (Mediagnost, Germany) and cytokeratin-18 (CK-18) (IDL Biotech, Sweden) were determined.

The statistical processing of the study results was carried out on a personal computer with the help of the standard applications Microsoft Excellence and SPSS Statistics 20 Multilingual. The mean values $(\mathrm{M})$, the arithmetic mean ( $\mathrm{t}$ ), and the validity of the differences $p$ according to Student's $t$-distribution were evaluated. The difference in indices for various periods of the study was considered significant at $P<0.05$. To determine the relationship between the indicators, Kendall's tau-b correlation coefficient was used.

\section{Results}

The analysis of the fibrosing reactions degree in NASH revealed a significant increase in blood PBOP content in patients of all groups: group 1 - by 1.27 times, group 2 - by 4.34 times, group 3 - by 5.02 times compared to the PHP $(P<0.05)$, which indicated a high activity of collagen anabolism in this contingent of individuals.

The blood content of FOP (Table 1) which is the biochemical marker for collagen catabolism, varied as follows: in the patients of group 1 - increased by 1.27 times, in patients of group 2 - decreased by 1.25 times, in patients of group 3 -increased by 1.31 times compared to the PHP $(P<0.05)$.

Regarding the glycosaminoglycan and glycoprotein components of CT metabolism in patients with steatohepatitis, the following results should be mentioned. In particular, the content of GA in patients of all groups was increased: in group 1 - by 1.71 times, in group 2 - by 1.22 times, in group 3 - by 1.4 times compared to the PHP $(P<0.05)$. At the same time, SA serum levels in the patients of all groups were increased more intensively: by $1.38,1.93$ and 3.41 times $(P<0.05)$, respectively (Table 1$)$. It should be noted that GA and SA contents were strongly directly correlated with the indicators of inflammatory process and cytolysis degree in the liver: between serum GA content and ALT activity $(r=0.62, P<0.05)$, between GA content and AST activity $(r=0.64, P<0.05)$, between SA content and ALT activity $(r=0.71, P<0.05)$, as well as between GA content and $y$-globulins level $(r=0.64, P<0.05)$.

Indicators of non-protein bound fucose (NPBF) content were also increased significantly in patients of all groups by $1.96,1.71$ and 2.12 times, respectively (Table 1$)$, and exceeded the content of those in the PHP group $(P<0.05)$. The obtained data testify that in NASH patients with $\mathrm{OB}$ there is an induction of catabolism of fucoglycoproteins of extracellular matrix (ECM), which is the most intense in OA comorbidity.

Plasma inhibitory activity is represented by a1-proteinase inhibitor ( $\alpha 1-\mathrm{PI})$ and $\alpha 2-$ macroglobulin ( $\alpha 2-\mathrm{MG})$ in $95 \%$. In particular, we found significant $(P<0.05)$ increase in a2-MG content in patients of all groups: in group 1 - by 1.53 times, in group 2 - by 1.3 times, in group 3 - by 1.74 times in comparison with that in the control group. Patients with NASH and OB had the lowest a2-macroglubulin content, which contributed to diffuse liver fibrosis development in response to chronic inflammation. A reverse correlation between the indices of serum FOP content and a2-MG $(r=-0.53, P<0.05)$ was established.

An analysis of changes in blood components of other ECM elements of protein origin, namely ceruloplasmin, showed its increase in patients of all groups with a significant prevalence among patients of group $3(P<0.05)$. Serum ceruloplasmin content in patients of this group was directly correlated with the indicators of cytolysis syndrome activity: with ALT $(r=0.64, P<0.05)$ and AST $(r=0.65, P<0.05)$. We established a strong direct correlation between indicators of serum ceruloplasmin and activity of alkaline phosphatase (ALP) $(r=0.71, P<0.05)$.

The analysis of serum leptin level in the studied groups revealed the following significant changes: in a combined progression of $\mathrm{NASH}, \mathrm{OA}$ and $\mathrm{OB}$, its highest concentration was observed and it was 5.02 times higher than in the control $(\mathrm{P}<0.05)$ (Table 2). In individuals with NASH secondary to $\mathrm{OB}$, the level of leptin was 4.34 times higher than that

Table 1. Indicators of metabolic state of connective tissue in NASH patients with obesity and osteoarthritis comorbidities $(\mathrm{M} \pm \mathrm{m})$

\begin{tabular}{|c|c|c|c|c|}
\hline & $\begin{array}{l}\text { Practically healthy persons } \\
(n=30)\end{array}$ & $\begin{array}{l}\text { OA with normal body weight } \\
(\mathrm{n}=30) 1 \text { group }\end{array}$ & $\begin{array}{l}\text { NASH + OB } \\
(n=30) 2 \text { group }\end{array}$ & $\begin{array}{l}\mathrm{NASH}+\mathrm{OB}+\mathrm{OA} \\
(\mathrm{n}=30) 3 \text { group }\end{array}$ \\
\hline PBOP, $\mu \mathrm{mol} / \mathrm{l}$ & $39.89 \pm 0.30$ & $56.96 \pm 0.30^{*}$ & $64.08 \pm 0.31^{* 0}$ & $86.44 \pm 0.34^{\star 0 x}$ \\
\hline $\mathrm{FOP}, \mu \mathrm{mol} / \mathrm{l}$ & $11.98 \pm 0.34$ & $18.51 \pm 0.32^{*}$ & $9.61 \pm 0.43^{* 0}$ & $15.66 \pm 0.42^{* 0 x}$ \\
\hline $\mathrm{GA}, \mathrm{mmol} / \mathrm{l}$ & $5.77 \pm 0.29$ & $9.87 \pm 0.27^{\star}$ & $7.02 \pm 0.28^{* 0}$ & $8.07 \pm 0.25^{\star 0 x}$ \\
\hline $\mathrm{SA}, \mathrm{mmol} / \mathrm{l}$ & $2.24 \pm 0.16$ & $3.10 \pm 0.13^{*}$ & $4.33 \pm 0.13^{* 0}$ & $7.64 \pm 0.15^{\star 0 x}$ \\
\hline NPBF, $\mu \mathrm{mol} / \mathrm{l}$ & $37.87 \pm 0.63$ & $74.32 \pm 0.52^{*}$ & $64.84 \pm 0.53^{\star 0}$ & $80.45 \pm 0.44^{* 0 x}$ \\
\hline $\mathrm{CP}, \mathrm{mmol} / \mathrm{l}$ & $12.18 \pm 0.33$ & $14.58 \pm 0.38^{*}$ & $15.40 \pm 0.41^{*}$ & $22.38 \pm 0.34^{* 0 x}$ \\
\hline$\alpha 2-M G, \mu \mathrm{mol} / /$ & $2.42 \pm 0.09$ & $3.70 \pm 0.09^{*}$ & $3.18 \pm 0.07^{\star 0}$ & $4.21 \pm 0.05^{* 0 \times}$ \\
\hline
\end{tabular}

*: the difference in indicators is significant $(P<0.05)$ as compared with the group of practically healthy individuals; ${ }^{\circ}$ : the difference in indicators is significant $(P<0.05)$ between group 1 and groups 2 and $3 ; \times$ : the difference in indicators is significant $(P<0.05)$ between groups 2 and 3 .

Table 2. Indicators of the serum content of leptin, adiponectin and cytokeratin-18 in NASH patients with obesity and osteoarthritis comorbidities (M $\pm m$ )

\begin{tabular}{l|l|l|l|l} 
& $\begin{array}{l}\text { Practically healthy persons } \\
(\mathrm{n}=30)\end{array}$ & $\begin{array}{l}\text { OA with normal body weight } \\
(\mathrm{n}=30) \mathbf{3} \text { group }\end{array}$ & $\begin{array}{l}\text { NASH + OB } \\
(\mathrm{n}=30) 2 \text { group }\end{array}$ & $\begin{array}{l}\text { NASH + OB+OA } \\
(\mathrm{n}=30) 3 \text { group }\end{array}$ \\
\hline Leptin, $\mathrm{ng} / \mathrm{ml}$ & $10.05 \pm 0.54$ & $12.80 \pm 0.60^{*}$ & $43.62 \pm 0.55^{* 0}$ & $50.47 \pm 0.71^{* 0 \times}$ \\
\hline Adiponectin, $\mathrm{ng} / \mathrm{ml}$ & $8.42 \pm 0.55$ & $6.73 \pm 0.50^{*}$ & $4.03 \pm 0.21^{* 0}$ & $5.72 \pm 0.41^{* \times}$ \\
Cytokeratin 18, $\mathrm{U} / \mathrm{l}$ & $60.00 \pm 2.29$ & $124.53 \pm 1.53^{*}$ & $266.50 \pm 9.49^{* 0}$ & $318.80 \pm 15.44^{* 0 \times}$ \\
\hline
\end{tabular}

*: the difference in indicators is significant $(P<0.05)$ as compared with the group of practically healthy individuals; ${ }^{0}$ : the difference in indicators is significant $(P<0.05)$ between group 1 and groups 2 and $3 ; x^{*}$ the difference in indicators is significant $(P<0.05)$ between groups 2 and 3 . 
in the control group; in patients with $\mathrm{OA}$ and normal BMI, this indicator was 1.27 times higher compared to the PHP $(P<0.05)$ with a significant intergroup difference.

The analysis of serum adiponectin revealed a decrease in their content in all study groups. In individuals with NASH and morbid $\mathrm{OB}$, this indicator was the lowest and significantly 2.09 times $(P<0.05)$ lower then in the PHP group. In combined course of NASH with $\mathrm{OA}$ and $\mathrm{OB}$, the level of serum adiponectin was 1.47 times lower in comparison with the PHP $(P<0.05)$. In the group of patients with $O A$ and normal $B M l$, this indicator was 1.25 times lower than in the PHP $(P<0.05)$ with a significant intergroup difference.

Analyzing the level of cytokeratin-18 in the comparison groups, we found that it 2.08 times exceeded the control indicators in the patients of group 1 ; in the patients of group 2 , it was 4.44 times higher in the control group, and 5.31 times higher in the patients of group 3. That is, we can say that in NAFLD patients at the stage of NASH, especially in the case of comorbidity, plasma levels of cytokeratin-18 were significantly increased.

As a result of the correlation analysis between the indices of the CT metabolism, adipokines and cytokeratin-18, the following data were obtained: adiponectin content was directly correlated with the content of FOP $(r=0.47$, $P<0.05)$ and $G A(r=0.42, P<0.05)$. The indicators of leptin were directly correlated with the content of PBOP $(r=0.65, P<0.05), S A(r=0.66, P<0.05)$, NPBF $(r=0.55$, $P<0.05)$ and $C P(r=0.63, P<0.05)$. It should be noted that the indices of cytokeratin-18 were directly correlated with the indices of CT metabolism, in particular with the content of PBOP $(r=0.72, P<0.05)$, GA content $(r=0.43$, $P<0.05)$ and $S A(r=0.72, P<0.05)$, with the content of $\operatorname{NPBF}(r=0.65, P<0.05)$ and $\mathrm{CP}(r=0.74, \mathrm{P}<0.05)$.

The optimal distribution points of the CK-18 biomarker for the diagnosis of liver steatosis in patients with $\mathrm{OA}$ and $\mathrm{OB}$ were determined using the ROC-analysis. The indicator had an area under the curve (AUC) of more than 0.8 (0.89), indicating the value of the selected biomarker (high quality model). Consequently, based on the performed $\mathrm{ROC}$ analysis, it has been proved that CK-18 is a sensitive marker associated with the presence of liver steatosis and can be used for early diagnosis of NASH in patients with $\mathrm{OA}$ and $\mathrm{OB}$.

\section{Discussion}

According to the study results, an increase in the synthesis of collagen accompanied by a decrease in the processes of newly formed collagen resorption was found in NASH patients, while in $\mathrm{OA}$, there was a catabolic activation of the extracellular matrix structural components induced by proteolytic enzymes overexpression. Thus, there was a degradation of collagen fibrils consisting mainly of type I collagen. In particular, these processes could be activated as a result of adipokines action, which are secreted by adipose tissue and affect the functions of cartilage and bone tissue.

High serum levels of GA and SA in NADH patients, especially in $\mathrm{OA}$ and $\mathrm{OB}$ comorbidities, could contribute to so-called collagen cementation in ECM reducing the probability of its resorption.

The obtained data indicate that there was a significant increase in the synthesis of collagen and glycosaminogly- cans in NASH patients with OB and OA, which was accompanied by ineffective resorption of newly formed collagen due to inhibition of collagenolytic activity of blood plasma in NASH, arising from activation of proteinase inhibitors ( $\alpha 2-M G$ ), a significant imbalance in the metabolic system of $\mathrm{CT}$, which, particularly in $\mathrm{OA}$ and $\mathrm{OB}$ comorbidities, leads to progressive fibrosis of the liver and its functions impairment.

The combined course of NASH, OA and OB was characterized by adipokine imbalance, which manifested itself in the increase in leptin serum level and the decrease in adiponectin.

Cytokeratin-18 (CK-18) is one of the most promising markers for diagnosis of NAFLD. It is believed that apoptosis of hepatocytes plays a crucial role in NAFLD progression, liver fibrosis and cirrhosis formation. In the development of apoptosis of hepatocytes, caspases, which cleave cytokeratin-18, are generally activated [8]. Numerous studies have shown that these cleaved fragments can be detected using monoclonal antibodies.

CK-18 is the main cytoskeletal protein of hepatocytes and other epithelial cells. It has been previously reported as circulating mechanistic indicator of cell death [6]. Two forms of CK-18 can be observed in blood plasma: the full-length form (CK-18 M65) and the caspase-cleaved form (CK-18 M30). The CK-18 M65 is used to assess necrosis, while the CK-18 M30 is used specifically to evaluate the rate of apoptosis [4].

The accumulated data indicate that hepatocyte apoptosis plays an important role in chronic liver disease [13]. By a meta-analysis of eight case-controlled studies, the researchers found that plasma levels of CK-18 could be a significant risk factor for $\mathrm{NASH}$, chronic hepatitis $\mathrm{C}$ $(\mathrm{CHC})$ and chronic hepatitis $\mathrm{B}(\mathrm{CHB})$ [12]. Some reports also showed that plasma levels of the CK-18 M30 were associated with NASH progression in obese patients [9].

The above data suggest that adipokines and cytokeratin-18 are sensitive markers of hepatocyte apoptosis, CT imbalance, and, consequently, the progression of liver fibrotic changes.

\section{Conclusions}

In patients with $\mathrm{NASH}$ and morbid $\mathrm{OB}$, a significant increase in collagen and glycosaminoglycans synthesis was observed. It was accompanied by an ineffective resorption of newly formed collagen due to collagenolytic activity of blood plasma inhibition in NASH resulted from activation of proteinase inhibitors ( $\alpha 2-M G)$, significant imbalance in the CT metabolism, which was worsened by accompanying OA leading to progressive liver fibrosis and dysfunction.

Taking into account that adiponectin was found to be positively correlated with the insulin sensitivity indices, active in body weight regulation, proinflammatory agent in joint diseases and involved in degradation of articular cartilage matrix, the adipokine deficiency, found in the work, may play a significant pathogenetic role in the development and progression of $\mathrm{NASH}$ as well as $\mathrm{OB}$ and $\mathrm{OA}$.

Thus, the blood level of adipokines and CK-18 not only depends on body weight, but also reflects the risk for occurrence of nosologies associated with OB. Besides, leptin and adiponectin may serve as sensitive risk markers for 
comorbid diseases development and could be candidates for their measurements inclusion in the diagnostic algorithm for $\mathrm{NASH}, \mathrm{OA}, \mathrm{OB}$ and their combination.

The prospect of further research. The study of the CT metabolism, the content of adipokines and CK-18 under the influence of various hepatotropic drugs in NASH with $\mathrm{OB}$ and $\mathrm{OA}$ comorbidities.

\section{Funding}

The study was carried out on the basis of the Higher State Educational Establishment of Ukraine "Bukovinian State Medical University" and is a part of scientific research work of the Department of Internal Medicine, Clinical Pharmacology and Occupational Diseases "Features of the Comorbidity of Diseases of Internal Organs: Risk Factors, Mechanisms of Development and Interaction, Pharmacotherapy" (State registration number: 0114U002475)

Conflicts of interest: authors have no conflict of interest to declare. Конфлікт інтересів: віАсутній.

Надійшка Ао редакції / Received: 28.09.2018

Після Аоопрацювання / Revised: 19.10.2018

Прийнято Ао Аруку / Accepted: 30.10.2018

Information about the authors:

Khukhlina O. S., MD, PhD, DSc, Professor, Head

of the Department of Internal Medicine, Clinical Pharmacology and Occupational Diseases, Bukovinian State Medical University,

Chernivtsi.

Liakhovych O. D., MD, Postgraduate Student of the Department of Internal Medicine, Clinical Pharmacology and Occupational Diseases, Bukovinian State Medical University, Chernivtsi. Kaniovska L. V., MD, PhD, Associate Professor of the Department of Internal Medicine, Clinical Pharmacology and Occupational Diseases, Bukovinian State Medical University, Chernivtsi. Kaushanska O. V., MD, PhD, Associate Professor of the Department of Internal Medicine, Clinical Pharmacology and Occupational Diseases, Bukovinian State Medical University, Chernivtsi.

Shuper V. O., MD, PhD, Associate Professor of the Department of Internal Medicine, Clinical Pharmacology and Occupational Diseases, Bukovinian State Medical University, Chernivtsi.

Відомості про авторів:

Хухиіна О. С., А-р меА. наук, професор, зав. каф. внутрішньої медицини, клінічної фармакології та професійних хвороб, BAНЗ “Буковинський Аержавний меАичний університет,, м. Чернівці, Україна.

^яхович О. А., аспірант каф. внутрішньої медицини, кмінічноі фармакології та професійних хвороб, ВАНЗ “Буковинський Аержавний медичний університет,, м. Чернівці, Україна. Каньовська ^. В., канА. меА. наук, Аоцент каф. внутрішньо медицини, кмінічної фармакології та професійних хвороб, ВАНЗ «Буковинський Аержавний меАичний університет, м. Чернівці, Україна.

Каушанська О. В., канА. меА. наук, Аоцент каф. внутрішньої медицини, кмінічної фармакології та професійних хвороб, ВАНЗ “Буковинський Аержавний меАичний університет”, м. Чернівці, Україна.

Шупер В. О., канА. меА. наук, Аоцент каф. внутрішньої медицини, кмінічної фармакології та професійних хвороб, ВАНЗ “Буковинський Аержавний меАичний університет”, м. Чернівці, Україна.

\section{Сведения об авторах:}

Хухлина О. С., А-р меА. наук, профессор, зав. каф. внутренней медицины, клинической фармакологии и профессиональных болезней, ВГУЗ "Буковинский государственный меАицинский университет", г. Черновцы, Украина.
Ляховыч О. А., аспирант каф. внутренней медицины, клинической фармакологии и профессиональных болезней, ВГУЗ “Буковинский госуАарственный меАицинский университет, г. Черновцы, Украина.

Канёвская А. В., канА. меА. наук, Аоцент каф. внутренней медицины, кминической фармакологии и профессиональных болезней, ВГУЗ «Буковинский государственный медицинский университет", г. Черновцы, Украина.

Каушанская Е. В., канА. меА. наук, Аоцент каф. внутренней медицины, клинической фармакологии и профессиональных болезней, ВГУЗ “Буковинский государственный меАицинский университет", г. Черновцы, Украина.

Шупер В. А., канА. меА. наук, Аоцент каф. внутренней медицины, клинической фармакологии и профессиональных болезней, ВГУЗ «Буковинский государственный медицинский университет,, г. Черновцы, Украина.

\section{References}

[1] Babak, O. Ya., \& Andreeva, A. O. (2013) Hormonalni zminy v zhyrovi tkanyni khvorykh na hipertonichnu khvorobu i ozhyrinnia [The hormona changes in adipose tissue in patients with hypertension against the background of obesity]. Ukrainskyi terapevtychnyi zhurnal, 1, 63-7. [in Ukrainian].

[2] Babak, O. Ya., \& Lapshyna, K. A. (2016) Lechebnaya taktika u pacientov s nealkogol'noj zhirovoj bolezn'yu pecheni s uchetom urovnya citokeratina-18 v plazme krovi [Therapeutic strategy in patients with non-alcoholic fatty liver disease, considering cytokeratin-18 level determination in blood plasma]. Suchasna hastroenterolohiia, 2, 15-20. [in Russian].

[3] Golovach, I. Yu. (2014) Osteoartrit: sovremennye fundamental'nye prikladnye aspekty patogeneza zabolevaniya [Osteoarthritis: modern fundamental and applied aspects of the pathogenesis of the disease] Bol'. Sustavy. Pozvonochnik, 3, 54-8. [in Russian].

[4] Dynnyk, N. V. (2016) Zastosuvannia neinvazyvnykh biomarkeriv ta mistse tsytokeratynu 18 u diahnostytsi patsiientiv z nealkoholnoiu zhyrovoiu khvoroboiu pechinky [The use of non-invasive biomarkers and cytokeratin 18 in the diagnosis of patients with non-alcoholic fatty liver disease]. Ukrainskyi naukovo-medychnyi molodizhnyi zhurnal, 2, 12-8. [in Ukrainian].

[5] Alam, S., Alam, M., Alam, S. M., Chowdhury, Z., \& Kabir, J. (2015) Prevalence and Predictor of Nonalcoholic Steatohepatitis (NASH) in Nonalcoholic Fatty Liver Disease (NAFLD). Journal of Bangladesh College of Physicians and Surgeons, 32(2), 71-77. doi: 10.3329/ jbcps.v32i2.26034

[6] Casteda, S., Roman-Blas, J. A., Largo, R., \& Harrero-Beaumont, G. (2014) Osteoartritis: a progressive disease with chaning phenotypes. Rheumatology (Oxford), 53(1), 1-3. doi: 10.1093 rheumatology/ket247

[7] Chakraborty, J. B., Oakley, F., \& Walsh, M. J. (2012) Mechanisms and biomarkers of apoptosis in liver disease and fibrosis. Int $\mathrm{J} \mathrm{Hepatol}$ 2012, 648915. doi: 10.1155/2012/648915

[8] Fujii, H., \& Kawada, N. (2012) Inflammation and fibrogenesis in steatohepatitis. J Gastroenterol, 47(3), 215-25. doi: 10.1007/s00535012-0527-x

[9] Haima, P. (2014) Non-invasive Detection of Liver Injury and Fatty Liver Disease. Use of the Apoptosis Specific Biomarker Cytokeratin-18 (ccK18) to detect non-alcoholic steatohepatitis (NASH) and predict progressive liver disease. Switzerland: TECOmedical Group. 16 p.

[10] K-Kutala, B., Bedossa, P., Guedj, J., Asselah, T., Martinot-Peignoux, M., Duval, X., \& Marcellin, P. (2015) Patients with chronic hepatitis C without advanced fibrosis and hepatocellular carcinoma: a retrospective clinical-pathological study. Dig Liver Dis., 47(4), 296-302. doi: 10.1016/j. dld.2014.12.010

[11] Liang, J., Liu, F., Wang, F., Han, T., Jing, L., Ma, Z., \& Gao Y. (2017) A Noninvasive Score Model for Prediction of NASHin Patients with Chronic HepatitisBand Nonalcoholic Fatty Liver Disease. Biomed Res Int, 2017, 8793278. doi: 10.1155/2017/8793278

[12] Rosso, C., Caviglia, G. P., Abate, M. L., Vanni, E., Mezzabotta, L. Touscoz, G. A., et al. (2016) Cytokeratin 18-Aspartate396 apoptotic fragment for fibrosis detection in patients with non-alcoholic fatty liver disease and chronic viral hepatitis. Dig Liver Dis., 48(1), 55-61. doi: 10.1016/j.dld.2015.09.008

[13] Yang, Z. H., Yang, S. X., Qin, C. Z., \& Chen, Y. X. (2015) Clinical values of elevated serum cytokeratin-18 levels in hepatitis: a meta-analysis. Hepat Mon, 15(5), e25328. doi: 10.5812/hepatmon.15(5)2015.25328 